\title{
A Geological Understanding of Lake Michigan's Shoreline Behavior
}

\section{Seasonal Sediment Movement}

The profile of Indiana's shoreline with Lake Michigan changes dramatically from year to year and systematically within a year. Sediment is always moving in the nearshore system of Lake Michigan. As a result, the onshore-offshore profile of Indiana's Lake Michigan shoreline changes seasonally and annually. During the summer months, sediment is transported onshore, widening the beach and creating a backshore platform for sun-bathing. By late fall and winter, sediment has been moved offshore by strong winds and waves and is stored on longshore sand bars. The winter storm beach profile is notably narrower and concave upward in the onshore zone. The next summer this sediment is once again moved back onto the beach with no significant change in overall sediment volume.

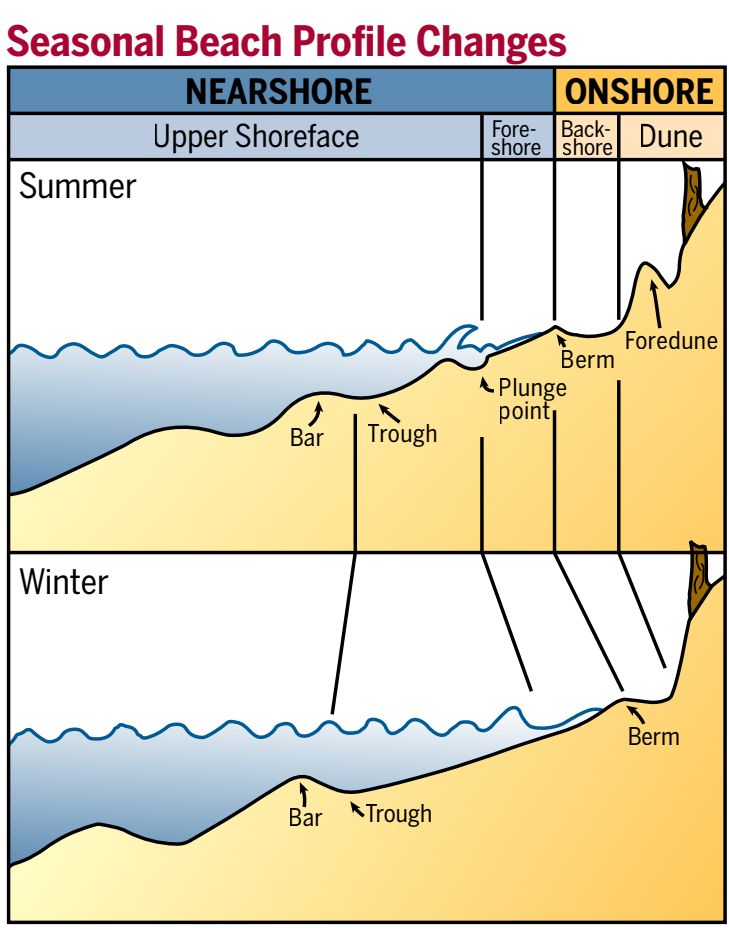

\section{Longshore Drift}

Longshore drift is the process of transporting sediment along the shore by waves and wave-induced currents that obliquely intersect the shoreline. While it is subtle, this sediment transport can best be seen when a wave surge drives grains and pebbles at an angle up the beach face. Meanwhile, much more sediment is being moved along the shore and out of sight under breaking waves. Although the direction of longshore sediment transport varies during a storm cycle, the net direction of sand and gravel transport along Indiana's coastline is from east to west.

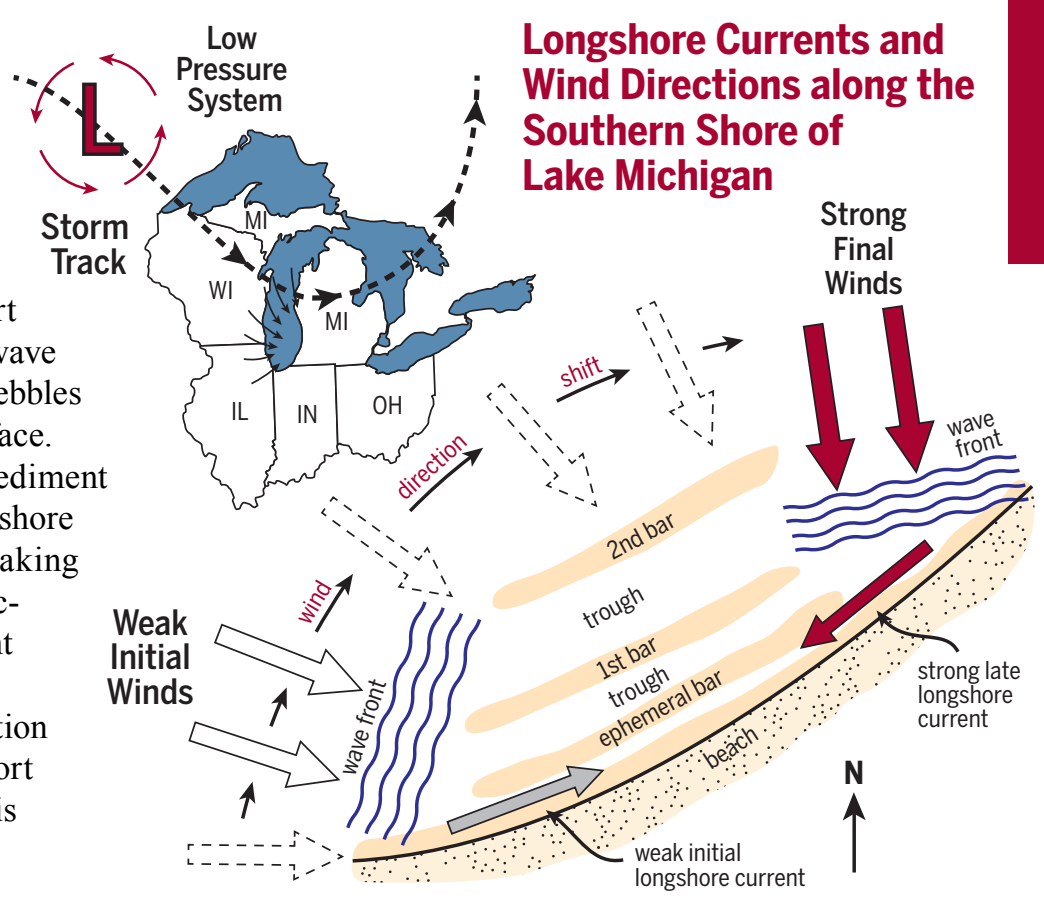

CURRENT SITUATION

The Lake Michigan shoreline

responds to changes in the

elevation of the lake, the

amount of sediment in the

system, and the waves and

currents impinging on the

shore. This response moves

sediment in the coastal

system in different ways,

producing both short-term

and long-term patterns of

shoreline behavior.

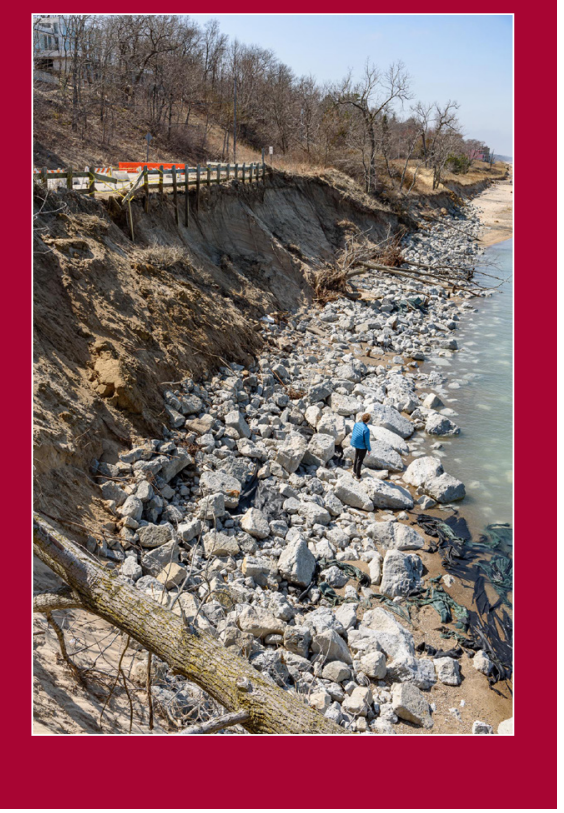

By Todd A. Thompson and

Erin P. Argyilan

DOI 10.14434/ijes.v2i0.31152

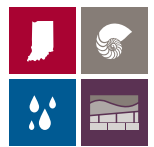

INDIANA GEOLOGICAL \& WATER SURVEY

INDIANA UNIVERSITY 


\section{Sediment Cells}

Natural barriers such as stream mouths and promontories and man-made barriers such as groins, jetties, and breakwaters can interrupt longshore drift. Hard structures along the shoreline, including rip rap and seawalls, also impact longshore and onshore-offshore sediment transport. In general, coastal sediment accumulates on the updrift side of the barrier (east), and sediment erodes on the downdrift side (west) in Indiana. When multiple barriers exist along a shoreline, the longshore pattern of sediment transport is dissected into smaller local sediment cells. In local cells, sediment is moved from one end of the cell to the other, causing local pockets of deposition and erosion along the shore. This erosion is especially visible within shoreline communities during high lake levels.

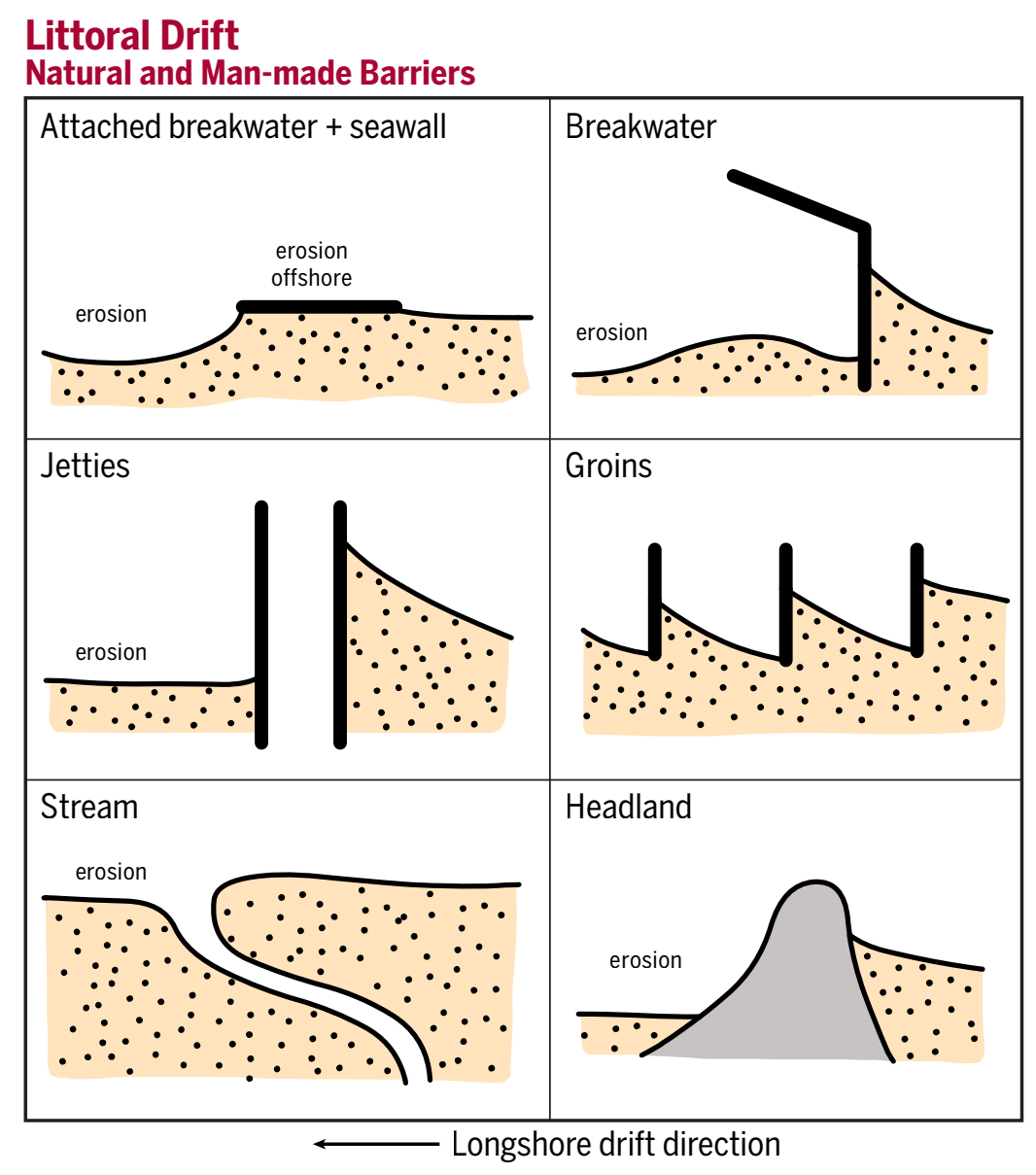

Four sediment cells occur along the Indiana coastline. The east-to-west transport of sediment within cells is ongoing, independent of lake level, establishing zones within each cell that can be described as generally erosional, depositional, or transitional with regard to long-term shoreline change. Erosion generally occurs on the east side of drift cells, while deposition occurs to the west. Some of the most dramatic erosion occurs at Mount Baldy in the Indiana Dunes National Park, located on the east side of Cell 2 East and west (downdrift) of the Michigan City Harbor.

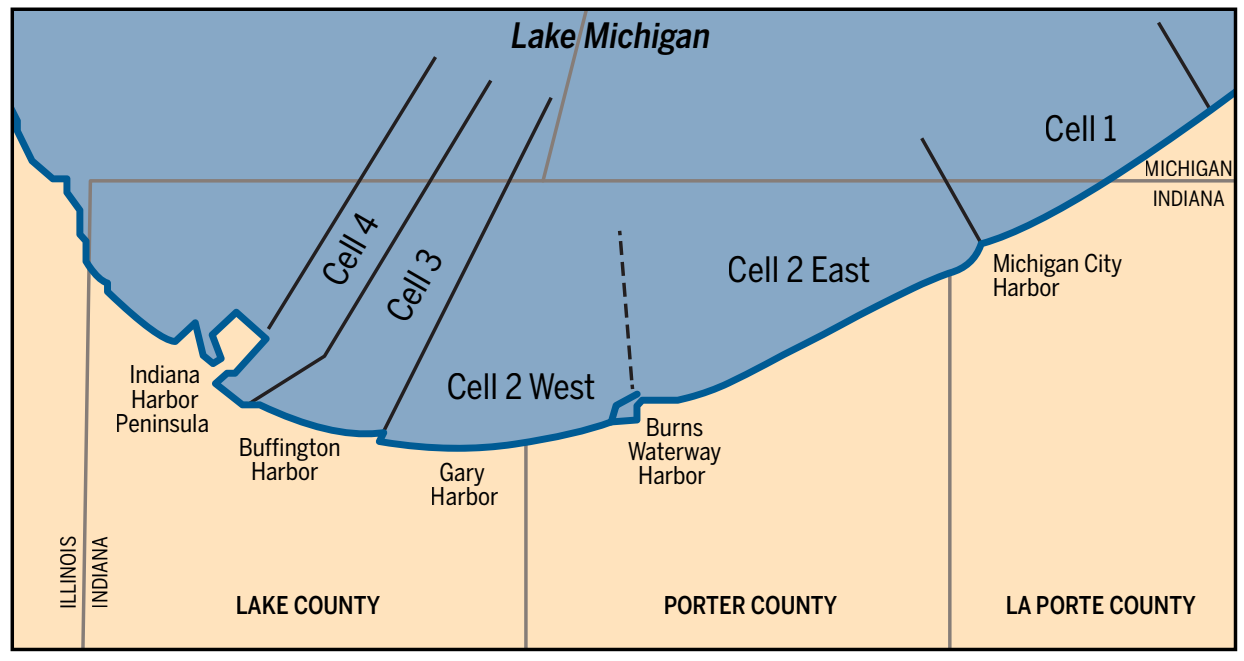

Argyilan, E. P., Johnston, J. W., Lepper, K., Monaghan, G. W., and Thompson, T. A., 2018, Lake-level, shoreline, and dune behavior along the Indiana southern shore of Lake Michigan [fieldtrip], in Florea, L. J., ed., Ancient Oceans, Orogenic Uplifts, and Glacial Ice-Geologic Crossroads in America's Heartland: Geological Society of America Field Guide 51, p. 181-203. https://dx.doi.org/10.1130/2018.0051(08)

Chrzastowski, M. J., and Thompson, T. A., 1994, Late Wisconsinan and Holocene geologic history of the Illinois and Indiana coast of Lake Michigan: Journal of Great Lakes Research, v. 20, p. 9-26. https://doi.org/10.1016/S0380-1330(94)71129-1

Chrzastowski, M. J., Thompson, T. A., and Trask, C. B., 1994, Coastal geomorphology and littoral cell divisions along the Illinois-Indiana coast of Lake Michigan: Journal of Great Lakes Research, v. 20, p. 27-43. https://doi.org/10.1016/S0380-1330(94)71130-8 